\title{
SARS-CoV-2: Characterisation and Mitigation of Risks Associated with Aerosol Generating Procedures (AGPs) in Dental Practices
}

\section{Touraj Ehtezazi}

Liverpool John Moores University

\section{David G. Evans}

Liverpool John Moores University

lan D. Jenkinson ( $\square$ i.d.jenkinson@ljmu.ac.uk)

Liverpool John Moores University

\section{Philip Evans}

Techceram Limited

\section{VJ Vadgama}

Woodbury Dental \& Laser Clinic

Jaimini Vadgama

Woodbury Dental \& Laser Clinic

Fadi Jarad

University of Liverpool School of Dentistry

Nicholas Grey

University of Manchester School of Dentistry

Robert P. Chilcott

University of Hertfordshire

\section{Research Article}

Keywords: dental, aerosol, AGPs, management, particle, size, fallow time,

Posted Date: November 13th, 2020

DOl: https://doi.org/10.21203/rs.3.rs-105294/v1

License: (c) (i) This work is licensed under a Creative Commons Attribution 4.0 International License.

Read Full License 


\section{Abstract}

The objectives of this study were to characterise the particle size distribution of aerosols generated by standard dental aerosol generating procedures (AGPs) and to assess the impact of aerosol management interventions on 'fallow time'. Aerosol management interventions included combinations of high-volume intra-oral suction (HVS(IO)), high volume extra-oral suction (HVS(EO)) and an air cleaning system (ACS). A sequence of six AGPs were performed in succession on a phantom head. Real-time aerosol measurements (size range $0.0062-9.6 \mu \mathrm{m}$ ) were taken using a high-resolution particle sizer acquiring air samples from six locations within a typical dental treatment room (35 m3). The majority $(>99 \%)$ of AGP particles were $<0.3 \mu \mathrm{m}$ diameter and remained at significant levels around the dental team during the AGPs. This emphasises the importance of personal protection equipment, particularly, the use of properly fitted respiratory protection to the appropriate (FFP3) standard. In the absence of active aerosol management interventions, AGP particles were estimated to remain above the baseline range for around 25-31 minutes from the end of the sequence of procedures. It was found that HVS(IO), either alone or in combination with the ACS, reduced particle concentrations to baseline levels on completion of AGPs. These data indicated that there is scope to reduce fallow time to 0 minutes.

\section{Key Points}

1. The particle size distribution of aerosols generated by dental procedures are predominantly $<0.3 \mu \mathrm{m}$ in diameter. This encompasses the reported size range of the SARS-CoV-2 virus $(0.05-0.15 \mu \mathrm{m})$.

2. Even in the presence of interventions such as high volume inter-oral suction HVS(IO) combined with an air cleaning system (ACS), aerosol particles $<0.3 \mu \mathrm{m}$ were substantially elevated above the baseline range during the dental aerosol generating procedures (AGP) used in this study (these included the use of air-turbine and electric handpieces operating at over $60,000 \mathrm{rpm})$. Levels of aerosol were especially elevated within the working micro-environment $(50 \mathrm{~cm}$ radius from the mouth) of the dentist and assistant. This emphasises the importance of properly fitted personal protective equipment such as FFP3 masks.

3. Intra-oral high-volume suction, either alone or in combination with an air cleaning system (in this case operating at 24 room air changes per hour in a typical $35 \mathrm{~m}^{3}$ surgery) was effective in rapidly reducing AGP-related particle concentrations to within background range in some cases, during or immediately, on cessation of AGPs negating the need for fallow time. These data indicate that a reduction in fallow time may be achieved below the current guidance of 10 minutes through judicious use of aerosol management interventions.

\section{Introduction}

Potentially infectious agents (e.g. bacteria, fungi and viruses) can be transmitted when droplets containing microorganisms generated from an infected person (example by breathing, talking or 
coughing) are propelled through the air and are directly inhaled, deposited on the skin or mucosal surfaces, or contaminate infrastructure. ${ }^{1}$ High-speed dental instruments require effective cooling of the work area in order to avoid damage of the pulp dentine system. These instruments generate a dental aerosol, as cooling water and air are sprayed around the instruments and the oral cavity.

Dental aerosols are distributions of particle sizes from 0.001 to $>10 \mu \mathrm{m}$ in diameter. ${ }^{2,3}$ Traditionally, dental airborne aerosols were defined as being small particles $<50 \mu \mathrm{m}$, with larger ballistic/projectile particles $(>50-100 \mu \mathrm{m})$ being described as "splatter". ${ }^{4}$ The WHO definition ${ }^{5}$ of aerosols has been adopted in the dental field, which defines large projectile particles as being $>5 \mu \mathrm{m}$, with smaller $(<5 \mu \mathrm{m})$ "droplet nuclei" particles forming through the evaporation of larger particles generating an airborne solid residue.

Infectious droplets from saliva or blood may enter the aerosol and expose the dental team to an increased risk of infection though direct inhalation, contact with eyes, and contact with contaminated work surfaces. ${ }^{6,7}$ Dental aerosols therefore have the potential to provide a path for the transmission of COVID-19 ${ }^{8,9}$ which may remain infectious for between 2 hours to 9 days in a humid environment. ${ }^{7}$ Research on the influenza virus has also demonstrated that the total viral copies were 8.8 times more numerous in particles $<5 \mu \mathrm{m}$ than in particles $\geq 5 \mu \mathrm{m} .{ }^{10}$ Previous studies have demonstrated the dispersion of bioaerosols to all areas of the treatment room ${ }^{11}$ which remain airborne for 30 minutes following the procedure. ${ }^{12}$ Therefore, there is a clear need for the effective removal of aerosols in dental practices. $^{13}$

Protocols exist to minimise the risk of infection to clinical staff during dental procedures. ${ }^{12,14-17}$ These include: low volume suction (LVS) to remove saliva and excess coolant, coolant disinfectant, high-volume intra-oral suction (HVS (IO)), personal protective equipment (PPE) and improved ergonomics and techniques (e.g. dental dams). A range of additional aerosol removal treatments have been proposed for use in dental procedures including extra-oral high volume suction (HVS (EO)), air cleaning systems (ACS), designed to filter, purify and recirculate room air) and ventilation systems. ${ }^{7,14,18,19}$ However, their effectiveness within a diverse range of dental practice environments is difficult to predict. $^{13}$

A wide range of ACS with different air flow rates and cleaning technology are commercially available or being marketed for dental use. However, dental practices have no clear standards or specifications to refer to before making an investment. HVS(EO) and $\mathrm{ACS}^{20,21}$ that contain high efficiency particulate air (HEPA) filters are effective in removing airborne particles with sizes greater than $0.3 \mu \mathrm{m}$ : viruses, such as coronaviruses, are in the size range of $0.05-0.15 \mu \mathrm{m}^{22}$ and thus may evade filtration. Hence, ACS have evolved to include the addition of technology such as UV-C lamps (99.97\% killing of H3N2 influenza virus), negative ion generators, and high pressure/voltage electrostatic plasma, which eliminate particles greater than $0.0146 \mu \mathrm{m}$. The efficiency of these air purifiers has not been evaluated for the removal aerosol particles in the presence of high volume intra-oral or extra-oral suction. 
Whilst researchers have studied aerosol removal treatments, few studies have examined their effectiveness across the full dental aerosol particle size distribution. For example, the use of HVS(IO) at air flow rates of $250-300 \mathrm{~L} \mathrm{~min}^{-1}$ is an established means of controlling dental aerosols but its effectiveness is based on a qualitative assessment of visible particles or particles greater than 0.65

$\mu \mathrm{m} .{ }^{19,23}$ Viruses are smaller than $0.65 \mu \mathrm{m}$ and therefore the efficacy of HVS(IO) studies are not relevant to COVID 19.

The objectives of this current study were to characterise the aerosols generated by standard dental procedures and to investigate the effectiveness of different combinations aerosol management interventions across the particle distribution range from 0.0062 to $10 \mu \mathrm{m}$ diameter to provide evidence for establishing a revised fallow time. A sequence of six standard dental procedures were performed in series to assess the effectiveness of four combinations of interventions based on HVS (IO), HVS (EO) and an ACS. The effectiveness of each intervention group was measured using a high-resolution particle size analyser, with air samples taken over a 36-minute period from six locations within a standard dental surgery.

\section{Method}

The study was performed within a dental surgery (dimensions $4.4 \times 3.1 \times 2.6 \mathrm{~m}$ : Figure 1). Real-time aerosol analysis was performed with a high-resolution Electric Low-Pressure Impactor particle sizer (HRELPI: "ELPI+", Dekati, Kangasala, Finland). The instrument recorded the concentration of particles detected within 100 pre-set 'bins' of particle size, ranging from 0.0062 to $9.6 \mu \mathrm{m}$, at a sampling frequency of $1 \mathrm{~Hz}$. Air samples were acquired at six locations (Figure 1, Table 1). Each position was measured relative to the phantom head on which the dental AGPs were performed. Air samples were directed to the ELPI+ via 2 m lengths of silicone tubing (Tygon ${ }^{\circledR}$ "; internal diameter $12.7 \mathrm{~mm}$, external diameter 17.5 $\mathrm{mm}$; Cole-Parmer Instrument Co, Illinois, USA: Figure S1). Each tube was individually connected to the particle sizer for a period of 30 seconds before being replaced with a tube from the next sampling location to enable a serial analysis of all six air sample locations within a 3 min cycle. A pilot study demonstrated that the tubing had no discernible effect on particle size measurements (see supplementary data: Annex A, Figures S1-S3). All non-experimental air-conditioning equipment was turned off during the experimental work, and the average room temperature and relative humidity were recorded at $27 \mathrm{C}$ and $67 \%$ respectively.

Each experiment comprised a three-minute baseline period, followed by a series of six aerosol generating procedures (AGPs) carried out over 18 minutes with a post-procedural duration of 18 minutes to monitor aerosol decay (Figure 2). Each experiment was performed using one of four treatments (Table 2). The technical specifications of each aerosol removal system are described in Table 3. Each treatment was performed in triplicate. The AGPs incorporated the serial use of six commonly used dental preparation instruments each of which were operated for three minutes within the phantom head, in the upper and lower anterior sextants, in the following order: (I) Air turbine hand-piece, (II) Electric contra-angle hand- 
piece, (III) Air turbine hand-piece, (IV) Three in one syringe, (V) Ultrasonic scaler and (VI) Ultrasonic scaler (Table 4).

Total particle concentration (calculated as the sum of particle concentrations over the 0.0062 to $9.6 \mu \mathrm{m}$ bin range) did not consistently exhibit a Gaussian (normal) or log-normal distribution and so excluded the use of parametric statistical tests. The low sample number $(n=3)$ precluded non-parametric analyses. Therefore, descriptive statistics were used and all particle concentration data are expressed as median values. Area under curve (AUC) calculations were performed using GraphPad Prism (v7.0e for Mac OS, GraphPad Software, La Jolla California USA). The AUC calculations reflect the total "dose" of aerosol (units of $\mathrm{mL} \mathrm{cm}^{-3} \mathrm{~min}$ ). The AUC calculations were used to assess the overall efficiency of each treatment and were expressed as the median value \pm minimum/maximum. Estimation of fallow time in the control treatment group was performed by linear regression of particle concentrations at each sample location following cessation of AGPs and was calculated as the time at which the extrapolated particle concentration decreased below the upper baseline particle concentration.

\section{Results}

The majority $(>99.9 \%$ ) of particles generated by the sequence of dental procedures (Figure 2$)$ were $<0.3$ $\mu \mathrm{m}$ diameter when sampled at the proximal position (Location 1: $8 \mathrm{~cm}$ ). Instruments I, II and III (Table 4) in the sequence generated the highest aerosol levels. Peak concentrations occurred between particle diameters 0.013 to $0.022 \mu \mathrm{m}$ (Figure $3, \mathrm{t}=3-6,6-9$, and 9-12 $\mathrm{min}$ ).

Aerosol generated under the control conditions (Table 2, intervention group A (LVS only)) was observed at all locations within the surgery and remained detectable at $15 \mathrm{~min}$ (Figure $3, t=36 \mathrm{~min}$ ) from the end of the last procedure (instrument $\mathrm{VI}$ at $\mathrm{t}=21 \mathrm{~min}$ ). The most persistent particles were in the range 0.012 to $0.025 \mu \mathrm{m}$. Particle concentrations decreased with increasing distance from the phantom head, with a notable, time-related decrease of particles in the range 0.054 to $0.236 \mu \mathrm{m}$ diameter. Particles $>0.05 \mu \mathrm{m}$ persisted at low concentrations $\left(\sim 25 \times 10^{3} \mathrm{~cm}^{-3}\right)$ for the duration of the study.

The particle size distributions generated during the use of all instruments and applying interventions B to $\mathrm{E}$ (Table 2) were like those in the control but with markedly reduced concentrations (Figure 3). Compared with control conditions all interventions produced a remarkable decrease in the number and distribution of particles detected in the extra-oral space (Location 2: $20 \mathrm{~cm}$ ) and more distal locations. Following the end of the sequence of procedures $(\mathrm{t}=21 \mathrm{~min})$ there was infrequent detection of low concentrations of aerosol particles from beyond the extra-oral space, and particles $>0.05 \mu \mathrm{m}$ were generally at the baseline level (Figure 3).

In the control group, total particle counts remained elevated above the baseline range for the duration of the experiment at all locations (Figure 4, and Figure S4). Therefore, for the control group linear regression was used to calculate the time needed for the total particle concentration at each location to return to baseline levels (Figure 10). This produced an estimated median time of 26 min (range $25-31 \mathrm{~min}$ ) from 
the end of the sequence of procedures ( $t=21 \mathrm{~min}$ ). In the case of experiments using either the HVS(IO), or the HVS(IO) combined with the ACS (Table 2, intervention groups B and C) the concentration of particles returned to within the baseline range at the end of the procedures ( $t=21 \mathrm{~min}$ ) (Figures 5, and 6 respectively). However, the total number of aerosol particles remained marginally above the baseline for interventions which included the HVS(EO) (Figures 7 and 8).

When the aerosol concentrations are expressed as dose $\left(\mathrm{mL} \mathrm{cm}^{-3} \mathrm{~min}\right)$ all interventions reduced total aerosol exposure (Figure 9). Intervention group B (Table 2, HVS(IO) with LVS) reduced the median dose by $80 \%$, while intervention group E (HVS(IO)+HVS(EO)+ACS with LVS) reduced the median dose by $90 \%$. However, HVS(IO) was noticeably less effective than intervention groups $\mathrm{C}, \mathrm{D}$ and $\mathrm{E}$ in controlling the range of (maximum-minimum) of the dose.

\section{Discussion}

The results of this study demonstrate that all the aerosol management interventions evaluated were relatively effective in controlling aerosols generated by dental handpieces. Most particles produced by our sequence of AGPs were $<0.3 \mu \mathrm{m}$. The use of either the HVS(IO), or the HVS(IO) combined with the ACS was enough to reduce the fallow time to 0 -min.

During AGPs the concentration of particles in the range 0.05 to $0.15 \mu \mathrm{m}$ diameter range is increased substantially. This size range corresponds to the reported size range of the SARS-CoV2 virus ( 0.05 to 0.15 $\mu \mathrm{m}){ }^{22}$ Within the working micro-environment (Locations $3-4,<50 \mathrm{~cm}$ ) the presence of active aerosol management interventions substantially reduces the concentration of airborne particles in this range but does not eliminate them. Thus it is important for dental workers to utilise both appropriate and properly fitted respiratory protective equipment such as FFP3 masks in combination with aerosol management interventions. ${ }^{24}$

In the absence of aerosol management interventions, particles in the range $0.05-0.236 \mu \mathrm{m}$, remained at elevated concentrations within the macro-environment (Locations 5-6, >50 cm) for longer than the experimental period. Our control study estimated that it may take at least 28 to 34 minutes after cessation of AGPs for the total particle concentration to return to baseline levels. Intervention groups $B$ and $\mathrm{C}$, which included the addition of HVS $(I 0)$, or HVS $(I O)$ with ACS, both had the effect of returning particle concentrations to within the baseline range by the end of the sequence of procedures i.e. no additional fallow-time was required before particle concentrations returned to baseline levels. In the case of interventions $D$ and $E$, which included HVS(EO), particle concentrations remained marginally above the baseline which is in agreement with previous work. ${ }^{19}$

Interventions $B$ and $C$ reduced particle concentrations in the macro-environment (Locations $-5-6,>50$ $\mathrm{cm}$ ) to within the baseline range during AGPs. Intervention C, (HVS(IO) in combination with an ACS) was effective in controlling both the median and the range (max-min) of the aerosol dose at all locations. In a dental surgery of the size used in this study $\left(35 \mathrm{~m}^{3}\right)$, and in the context of SARS-CoV-2, it provides further 
evidence to support a reduction in fallow time below the current recommend period of 10 minutes ${ }^{24}$ in agreement with other recent studies. ${ }^{25}$

The use of a phantom head is a clear limitation of this study: the presence of saliva and other biological materials within the oral cavity may conceivably affect the particle size distribution of AGPs and so further, confirmatory research should be performed using patients. Such work should incorporate different size surgeries to validate the scalability of aerosol mitigation interventions. It should also be noted that a locally moist and warm atmosphere within a "turbulent gas cloud" allows the contained continuum of droplet sizes to evade evaporation for much longer time periods than occurs with isolated droplets, from a fraction of a second to minutes. ${ }^{26}$ This may explain why the most persistent particles measured in our study were within the smaller, 0.012-0.025 $\mu \mathrm{m}$ range. Therefore, a patient-orientated study is needed to confirm the nature of the fine particle aerosols containing mixtures of saliva, coolant, and pathogens. This may provide further evidence to support the use of antiviral disinfectants in coolant solutions.

\section{Conclusions}

Dental AGPs produce aerosols characterised by particles $<0.3 \mu \mathrm{m}$ in diameter. Although, aerosol suppression treatments such as HVS(IO) alone or in combination with an ACS may rapidly reduce particle concentrations to within background range, they do not eliminate exposure during AGPs and so the use of appropriate respiratory protective equipment by dental practitioners is essential.

HVS $(I 0)$ combined with the ACS was enough to reduce the fallow time to 0 minute, and to control the median and range of the aerosol particle dose at all areas in the surgery. The ACS used in these experiments was set to deliver 24 air changes per hour in an $35 \mathrm{~m}^{3}$ surgery which was close to maximum and further experimental work is needed to optimise the location and setting of equipment of this type.

In the absence of ventilation within a modest sized $\left(35 \mathrm{~m}^{3}\right)$ surgery, particles associated with dental AGPs may persist for approximately half an hour. There appears to be scope for a reduction in fallow time from the current guideline of 10 minutes when effective aerosol management system(s) are used.

\section{Declarations}

\section{Acknowledgements}

This work was supported by the LJMU Corona Virus Rapid response grant. The authors wish to thank Tayyebeh Rafiei, Rhiannon Powell \& Ben Wilkinson for their efforts in assisting the data analysis. The authors would also like to express their gratitude to Louie Chen (Scielutions Ltd) \& Dekati Ltd Finland for the loan of the ELPI+ unit and their invaluable technical support. 


\section{Declaration of Interests}

The authors have not declared any conflict of interest. Techceram Ltd is a commercial entity in the dental field, but has no interest in any of the equipment used in the present study, only in contributing its network of contacts towards the present study, in order to better understand dental AGPs, so that dental hospitals, practices, labs and associated dental supply chain smaller businesses can remain open and operate safely through any future viral pandemics.

\section{References}

1 Jayaweera, M., Perera, H., Gunawardana, B. \& Manatunge, J. Transmission of COVID-19 virus by droplets and aerosols: A critical review on the unresolved dichotomy. Environmental research 188, 109819, doi:10.1016/j.envres.2020.109819 (2020).

2 Bogdan, A., Buckett, M. I. \& Japuntich, D. A. Nano-sized aerosol classification, collection and analysis-method development using dental composite materials. Journal of occupational and environmental hygiene 11, 415-426, doi:10.1080/15459624.2013.875183 (2014).

3 Day, C. J., Price, R., Sandy, J. R. \& Ireland, A. J. Inhalation of aerosols produced during the removal of fixed orthodontic appliances: a comparison of 4 enamel cleanup methods. American journal of orthodontics and dentofacial orthopedics : official publication of the American Association of Orthodontists, its constituent societies, and the American Board of Orthodontics 133, 11-17, doi:10.1016/j.ajodo.2006.01.049 (2008).

4 Micik, R. E., Miller, R. L., Mazzarella, M. A. \& Ryge, G. Studies on dental aerobiology. I. Bacterial aerosols generated during dental procedures. J Dent Res 48, 49-56, doi:10.1177/00220345690480012401 (1969).

5 Organisation, W. H. Infection prevention and control of epidemic and pandemic prone respiratory infections in health care. (WHO Library Cataloguing-in-Publication Data 2014).

6 Miller, R. Air Pollution in the Dental Office. Medical Clinics of North America 22, 453-476 (1978).

7 Peng, X. et al. Transmission routes of 2019-nCoV and controls in dental practice. International Journal of Oral Science 12, 9, doi:10.1038/s41368-020-0075-9 (2020).

8 Epstein, J. B., Chow, K. \& Mathias, R. Dental procedure aerosols and COVID-19. The Lancet Infectious Diseases, doi:https://doi.org/10.1016/S1473-3099(20)30636-8 (2020).

9 Ge, Z. Y., Yang, L. M., Xia, J. J., Fu, X. H. \& Zhang, Y. Z. Possible aerosol transmission of COVID-19 and special precautions in dentistry. Journal of Zhejiang University. Science. B 21, 361-368, doi:10.1631/jzus.B2010010 (2020). 
10 Milton, D. K., Fabian, M. P., Cowling, B. J., Grantham, M. L. \& McDevitt, J. J. Influenza virus aerosols in human exhaled breath: particle size, culturability, and effect of surgical masks. PLoS pathogens $\mathbf{9}$, e1003205, doi:10.1371/journal.ppat.1003205 (2013).

11 Rautemaa, R., Nordberg, A., Wuolijoki-Saaristo, K. \& Meurman, J. H. Bacterial aerosols in dental practice - a potential hospital infection problem? J. Hosp. Infect. 64, 76-81, doi:10.1016/j.jhin.2006.04.011 (2006).

12 Veena, H. R., Mahantesha, S., Joseph, P. A., Patil, S. R. \& Patil, S. H. Dissemination of aerosol and splatter during ultrasonic scaling: A pilot study. Journal of Infection and Public Health 8, 260-265, doi:https://doi.org/10.1016/j.jiph.2014.11.004 (2015).

13 Sachdev, R., Garg, K., Singh, G. \& Mehrotra, V. Is safeguard compromised? Surgical mouth mask harboring hazardous microorganisms in dental practice. J Family Med Prim Care 9, 759-763, doi:10.4103/jfmpc.jfmpc_1039_19 (2020).

14 Hallier, C., Williams, D. W., Potts, A. J. \& Lewis, M. A. A pilot study of bioaerosol reduction using an air cleaning system during dental procedures. Br Dent J 209, E14, doi:10.1038/sj.bdj.2010.975 (2010).

15 Mupparapu, M. \& Kothari, K. R. M. Review of surface disinfection protocols in dentistry: a 2019 update. Quintessence Int 50, 58-65, doi:10.3290/j.qi.a41337 (2019).

16 Sawhney, A. et al. Aerosols how dangerous they are in clinical practice. J Clin Diagn Res 9, Zc5257, doi:10.7860/jcdr/2015/12038.5835 (2015).

17 Joshi, A. A., Padhye, A. M. \& Gupta, H. S. Efficacy of Two Pre-Procedural Rinses at Two Different Temperatures in Reducing Aerosol Contamination Produced During Ultrasonic Scaling in a Dental Set-up A Microbiological Study. J Int Acad Periodontol 19, 138-144 (2017).

18 Teanpaisan, R., Taeporamaysamai, M., Rattanachone, P., Poldoung, N. \& Srisintorn, S. The usefulness of the modified extra-oral vacuum aspirator (EOVA) from household vacuum cleaner in reducing bacteria in dental aerosols. Int. Dent. J. 51, 413-416, doi:10.1002/j.1875-595X.2001.tb00853.x (2001).

19 Noro, A. et al. A study on prevention of hospital infection control caused by tooth preparation dust in the dental clinic. Part 1. Preventive measures against environmental pollution in the dental clinic caused by microbial particles. Bull. Tokyo Dent. Coll. 36, 201-206 (1995).

20 Zhao, B., An, N. \& Chen, C. Using air purifier as a supplementary protective measure in dental clinics during the COVID-19 pandemic. Infect. Control Hosp. Epidemiol., 1-4, doi:10.1017/ice.2020.292 (2020).

21 Hubar, J. S., Pelon, W., Strother, E. A. \& Sicard, F. S. Reducing Staphylococcus aureus bacterial counts in a dental clinic using an Ionic Breeze air purifier: a preliminary study. Gen Dent 57, 226-229 
(2009).

22 Lin, Y. et al. Probing the structure of the SARS coronavirus using scanning electron microscopy. Antivir Ther 9, 287-289 (2004).

23 Davies, M. H., Rosen, M., Eccles, J. D. \& Marshal, R. J. Criteria of air flow and negative pressure for high volume dental suction. Br. Dent. J. 130, 483-487, doi:10.1038/sj.bdj.4802680 (1971).

24 Programme, S. D. C. E. Mitigation of AGPs in Dentistry, A rapid review. Vol. 1.0.25 (2020).

25 R Holliday, J. A., CC Currie, DC Edwards, C Bowes, K \& Pickering, S. R., J Durham, N Rostami, J Coulter, $\mathrm{N}$ Jakubovics. Evaluating dental aerosol and splatter in an open plan clinic environment: implications for the COVID-19 pandemic. https://doi.org/10.31219/osf.io/md49f(2020).

26 Bourouiba, L. Turbulent Gas Clouds and Respiratory Pathogen Emissions: Potential Implications for Reducing Transmission of COVID-19. JAMA 323, 1837-1838, doi:10.1001/jama.2020.4756 (2020).

\section{Tables}

Table 1: Air sampling location coordinates, expressed relative to the phantom head (nominal coordinates $\mathrm{x}=0, \mathrm{y}=0, \mathrm{z}=0$ ).

\begin{tabular}{|c|c|c|c|c|c|}
\hline \multirow{2}{*}{$\begin{array}{c}\text { Sample } \\
\text { Location No. }\end{array}$} & Name & \multicolumn{3}{|c|}{$\begin{array}{c}\text { Co-ordinates relative to } \\
\text { phantom head (mm) }\end{array}$} & $\begin{array}{c}\text { Linear Distance from } \\
\text { source (mm) }\end{array}$ \\
\cline { 3 - 5 } & & $\mathbf{x}$ & $\mathbf{y}$ & $\mathbf{z}$ & \\
\hline 1 & $\begin{array}{c}\text { Phantom head } \\
\text { (source) }\end{array}$ & 0 & 80 & 0 & 80 \\
\hline 2 & $\begin{array}{c}\text { HVS (EO) in- } \\
\text { take }\end{array}$ & 135 & -110 & 100 & 200 \\
\hline 3 & Dentist & -262 & 145 & 265 & 400 \\
\hline 4 & Assistant & 354 & 160 & 300 & 500 \\
\hline 5 & Wall & 0 & 900 & 1045 & 1480 \\
\hline 6 & Light & 726 & 383 & 1495 & 1700 \\
\hline
\end{tabular}

Table 2: Summary of aerosol removal treatments used in each experiment. Note that intraoral low volume suction (LVS) was used in all treatment groups (including control) to represent standard practice and to prevent excess fluid accumulation within the phantom head. 


\begin{tabular}{|l|c|c|c|c|}
\hline & \multicolumn{5}{|c|}{ Interventions } \\
\cline { 2 - 5 } & $\begin{array}{l}\text { LVS } \\
\text { Low } \\
\text { volume } \\
\text { suction }\end{array}$ & $\begin{array}{l}\text { HVS(IO) } \\
\text { High Volume Suction (Intra- } \\
\text { oral) with air filtration system. }\end{array}$ & $\begin{array}{l}\text { HVS(EO) } \\
\text { High Volume } \\
\text { Suction (extra- } \\
\text { oral). }\end{array}$ & $\begin{array}{l}\text { ACS } \\
\text { Air } \\
\text { Cleaning } \\
\text { System. }\end{array}$ \\
\hline $\begin{array}{l}\text { Intervention } \\
\text { group }\end{array}$ & & & & \\
\hline A & $\mathrm{X}$ & $\mathrm{X}$ & & \\
\hline $\mathbf{B}$ & $\mathrm{X}$ & $\mathrm{X}$ & $\mathrm{X}$ & \\
\hline C & $\mathrm{X}$ & $\mathrm{X}$ & $\mathrm{X}$ & $\mathrm{X}$ \\
\hline $\mathbf{D}$ & $\mathrm{X}$ & $\mathrm{X}$ & & \\
\hline E & & $\mathrm{X}$ & & \\
\hline
\end{tabular}

Table 3: Aerosol suppressing equipment and corresponding air/water flow rates. Low volume suction (LVS) was used in all treatment groups. In this study, the air cleaning system (ACS) flow rate was equivalent to $\sim 20$ air changes per hour.

\begin{tabular}{|c|l|c|c|c|}
\hline Treatment & \multicolumn{1}{|c|}{ Equipment } & $\begin{array}{c}\text { Water } \\
\text { Flow (L } \\
\left.\text { min }^{-1}\right)\end{array}$ & $\begin{array}{c}\text { Air } \\
\text { Flow } \\
\left(\begin{array}{l}\text { min } \\
\text { 1) }\end{array}\right.\end{array}$ & $\begin{array}{c}\text { Air changes per } \\
\text { hour (in a 35 m } \\
\text { surgery }\end{array}$ \\
\hline LVS & $\begin{array}{l}\text { Plastcare USA, 4 mm slow speed salivary } \\
\text { ejector. }\end{array}$ & 2.4 & 79 & \\
\hline HVS(IO) & $\begin{array}{l}\text { Dürr Universal Cannula III 16 mm, connected } \\
\text { to Dürr Dental VSA 300S Dürr Dental UK, } \\
\text { Kettering, UK. }\end{array}$ & - & 297 & \\
\hline HVS(EO) & $\begin{array}{l}\text { Eighteeth VacStation, Sifary Medical } \\
\text { Technology, Jiangsu, China. }\end{array}$ & - & 3700 & 6 \\
\hline ACS & $\begin{array}{l}\text { Woodpecker Q7 Plasma Air Purifier, Guilin } \\
\text { Woodpecker Medical Instrument Co, Guilin, } \\
\text { China. }\end{array}$ & - & 14167 & 24 \\
\hline
\end{tabular}

Table 4: Procedural equipment and corresponding coolant flow rates. 


\begin{tabular}{|c|l|c|}
\hline Procedure & \multicolumn{1}{|c|}{ Description } & \multicolumn{1}{|c|}{$\begin{array}{c}\text { Coolant Flow Rate (mL } \\
\text { min }^{-1} \text { ) }\end{array}$} \\
\hline I & $\begin{array}{l}\text { W\&H Synea Vision TK94 hand-piece (Air Turbine) with long } \\
\text { tapered bur }\end{array}$ & 55 \\
\hline II & NSK Ti Max Z95L hand piece (Electric) with long tapered bur & 56 \\
\hline III & Sirona T1 Control hand-piece (Air turbine) with long tapered bur & 82 \\
\hline IV & 3 in1 syringe from Belmont Cleo II chair & 25 \\
\hline V & Cavitron Jet Plus Ultrasonic with 30K FSI-SLI tip & 78 \\
\hline VI & NSK Vario Lux 2 (Piezo) with G8 tip & \multicolumn{1}{|c|}{} \\
\hline
\end{tabular}

\section{Figures}

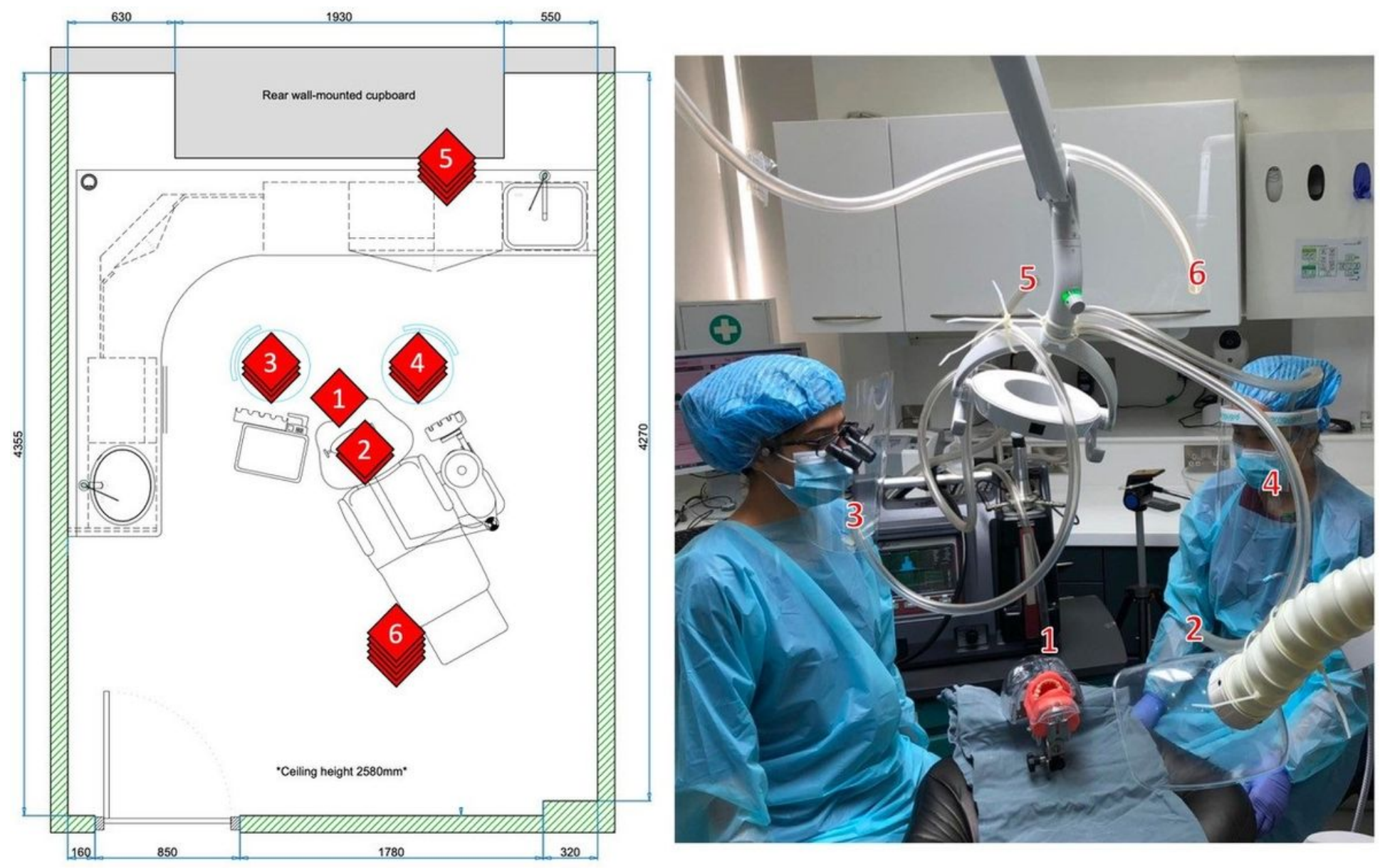

\section{Figure 1}

Layout and sampling positions of the dental treatment room. Note that tube location 6 was moved from the ceiling light fitting to be visible in the photograph. 


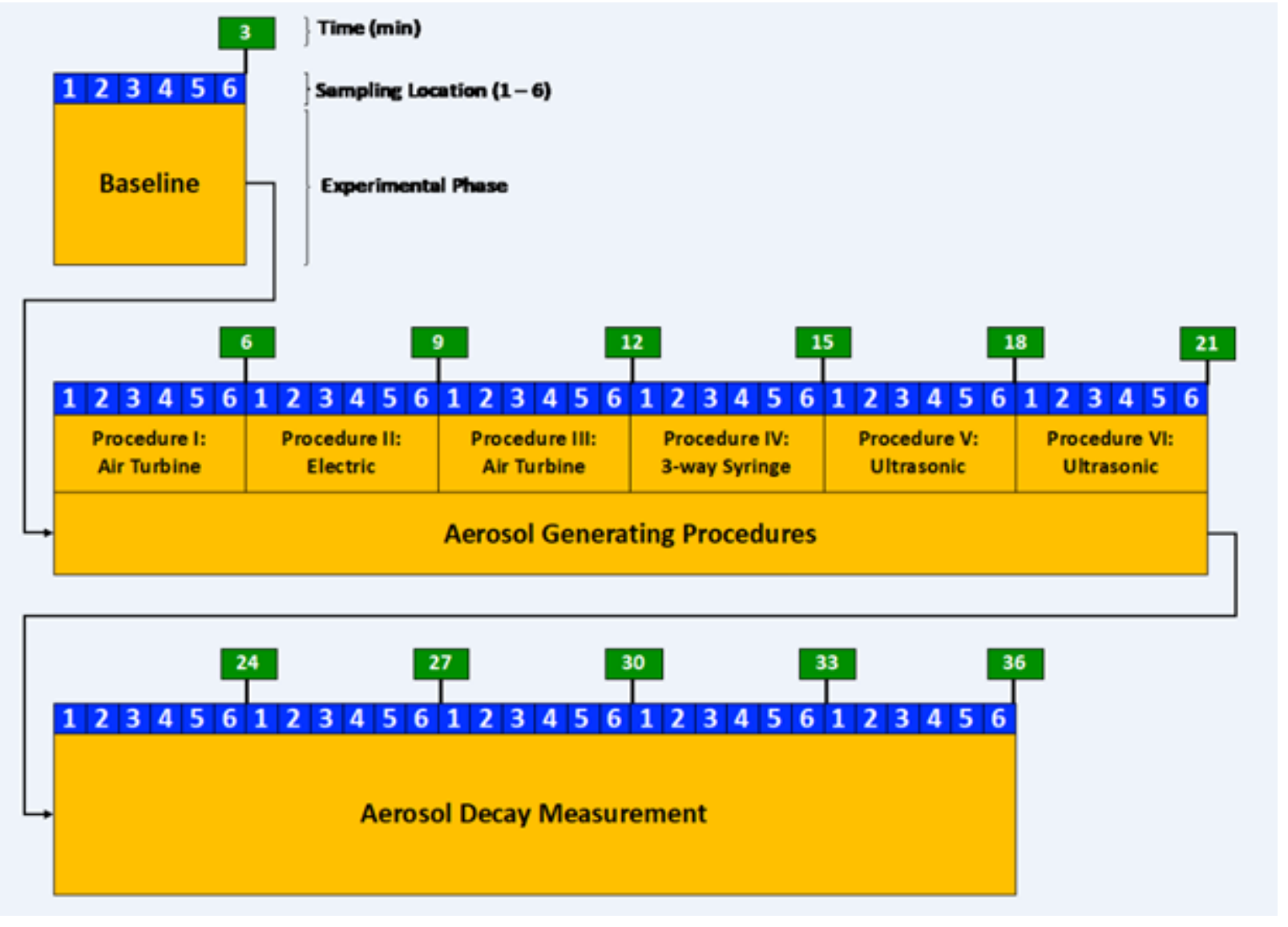

Figure 2

Outline study design. After an initial baseline period ( $3 \mathrm{~min}$ ), six aerosol generating procedures (I to $\mathrm{VI}$ ) were performed in series (18 $\mathrm{min}$ ) followed by a period to quantify aerosol decay kinetics (15 min). Air samples from each location $(1-6)$ were acquired over a 30 second period. The total duration of each experiment was 36 minutes. 


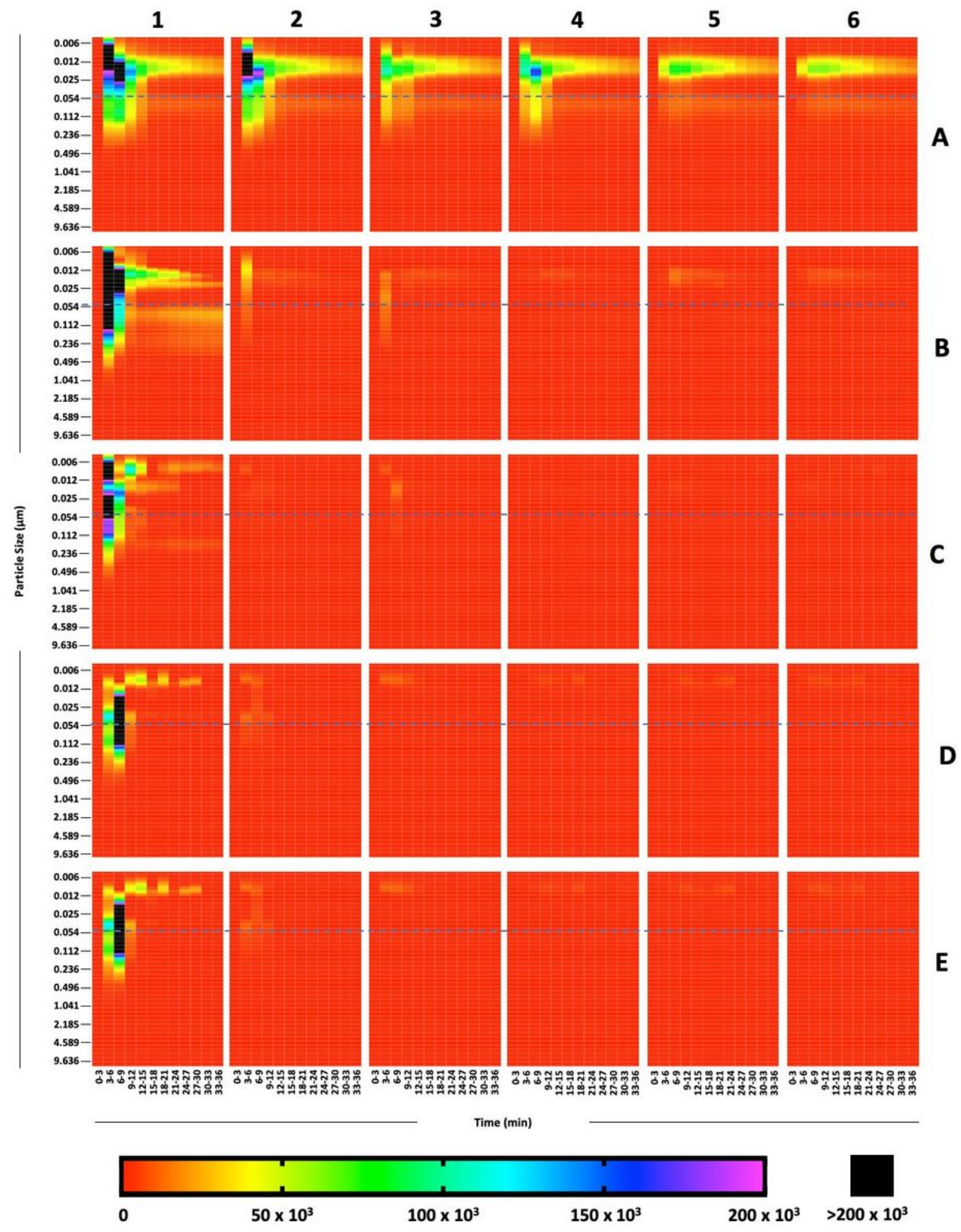

\section{Figure 3}

Temporal, spatial and size characterisation of particles generated during AGPs (measured by HR-ELPI) for each location (1 - 6; Table 1) and treatment group (A - E; Table 2). Acquisition of air samples were performed during the baseline period $(0-3 \mathrm{~min})$, during the six procedures $(3-18 \mathrm{~min})$ and following cessation of procedures (18 - $36 \mathrm{~min})$. Each data point represents the median particle concentration per 
size bin (\# cm-3) derived from $n=3$ replicates. The dotted lines indicate the lower reported size for a SARSCoV-2 virus particle (50 $\mathrm{nm}$ diameter).

1

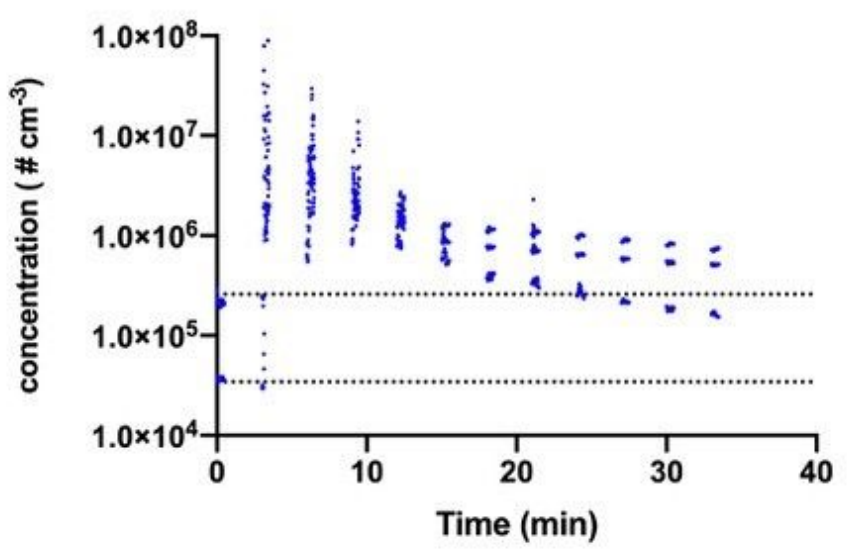

3

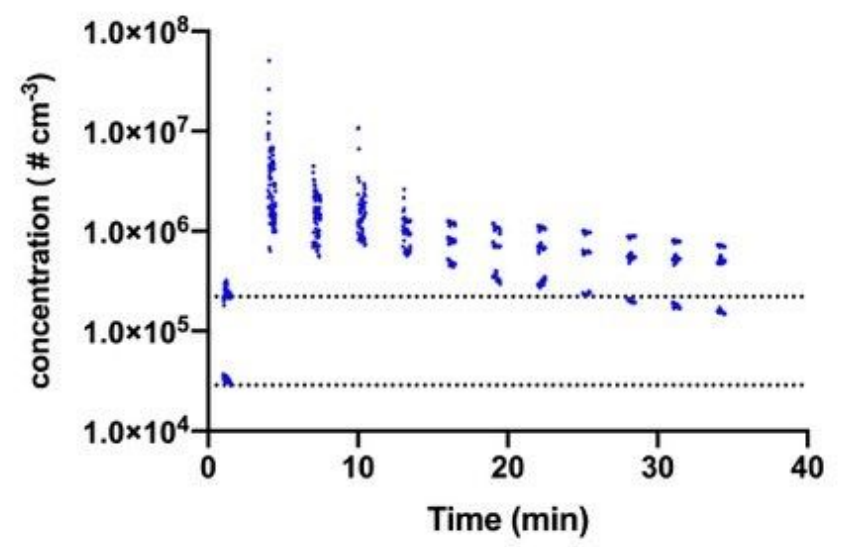

5

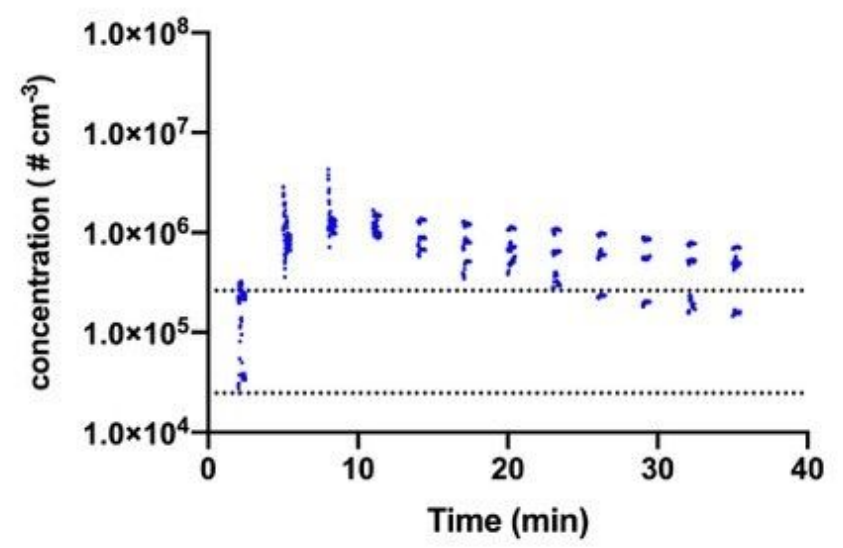

2

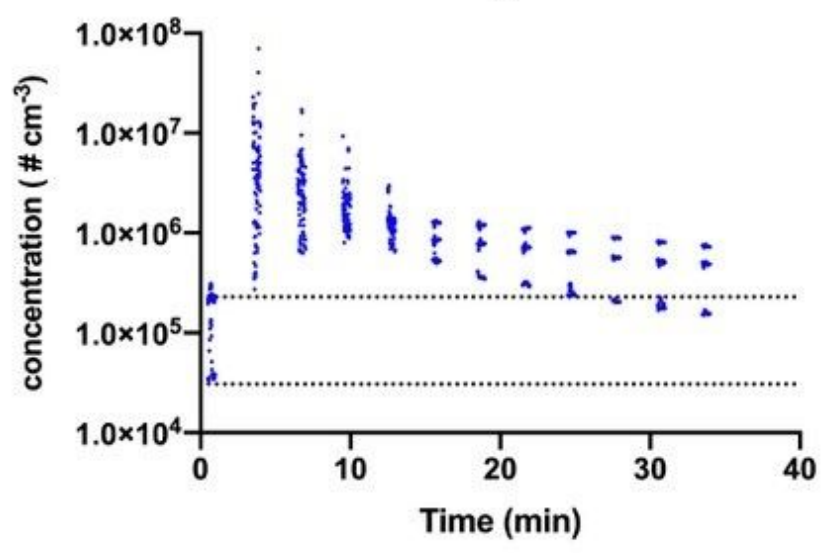

4

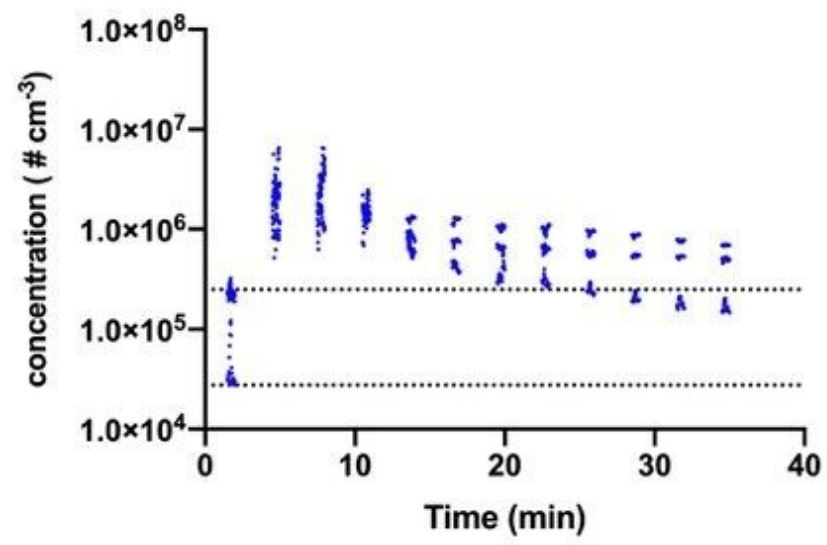

6

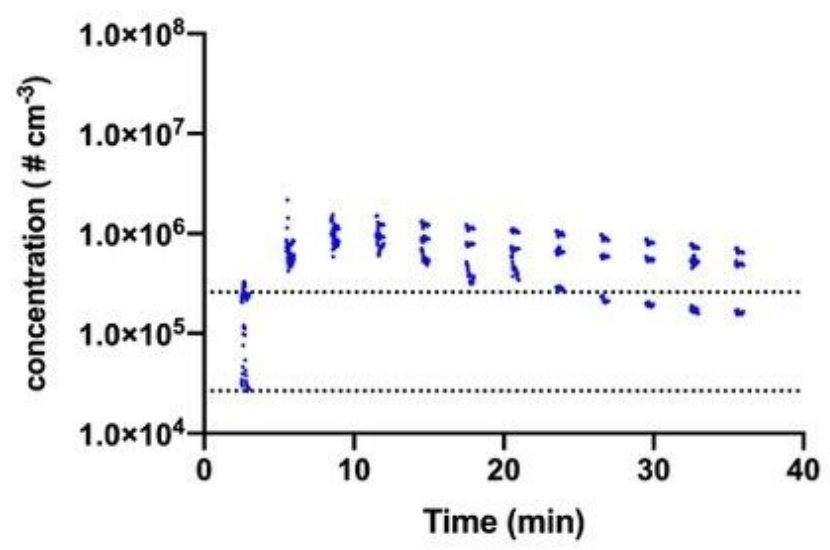

Figure 4

Total particle concentration generated during AGPs in the absence of interventions (group A; Table 2) at each air sampling location ( $1-6$; Table 1$)$. Acquisition of air samples were performed during the baseline period $(0-3 \mathrm{~min})$, during the six procedures $(3-18 \mathrm{~min})$ and following cessation of procedures $(18-36$ 
$\min )$. Dotted lines indicate the upper and lower boundaries of the baseline data. Each data point represents the sum of particles measured by HR-ELPI over 1 second during each replicate $(n=3)$.

1

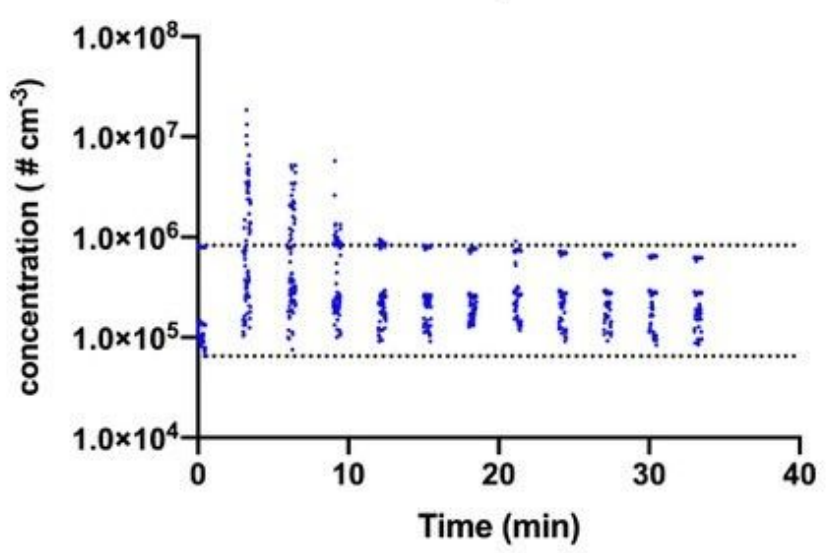

3

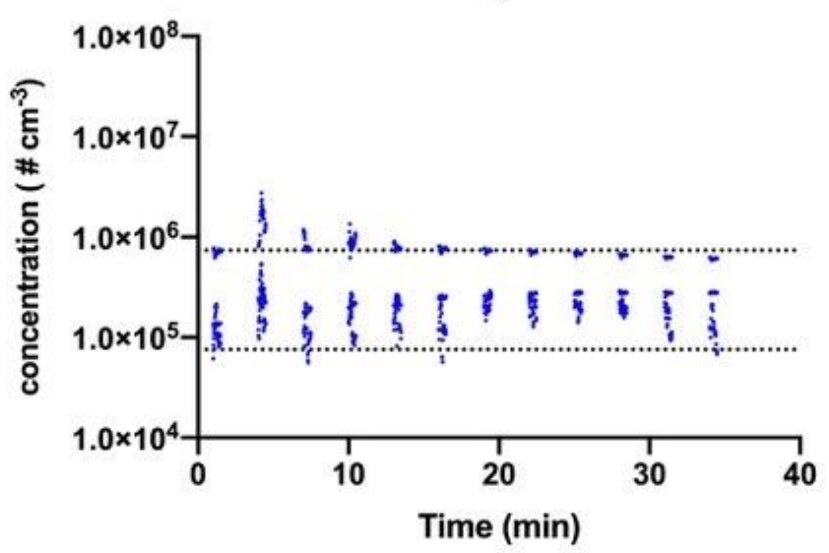

5

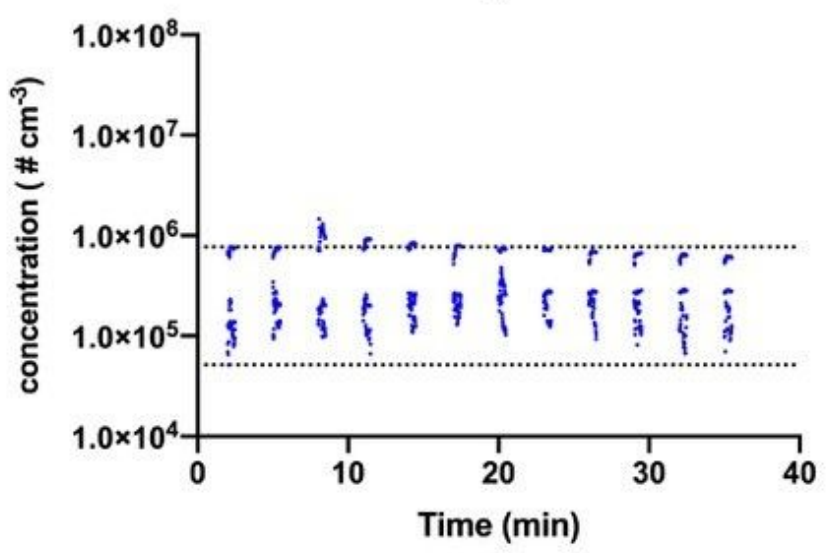

2

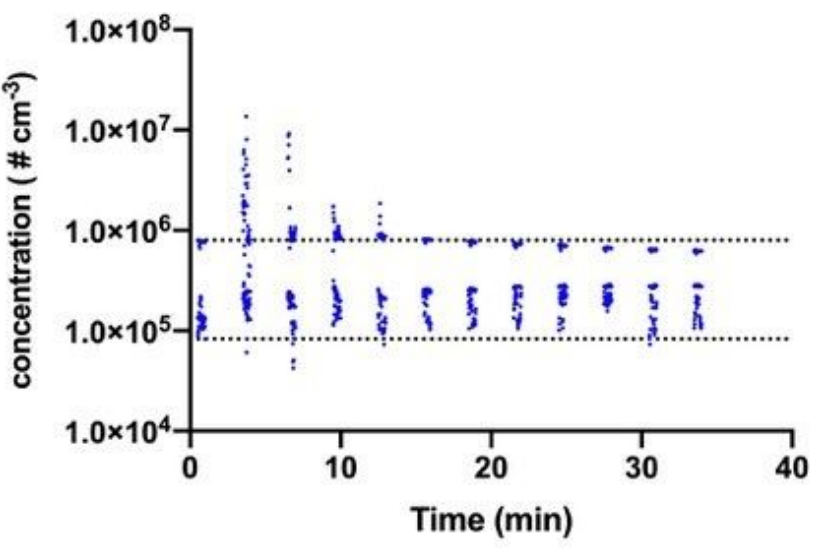

4

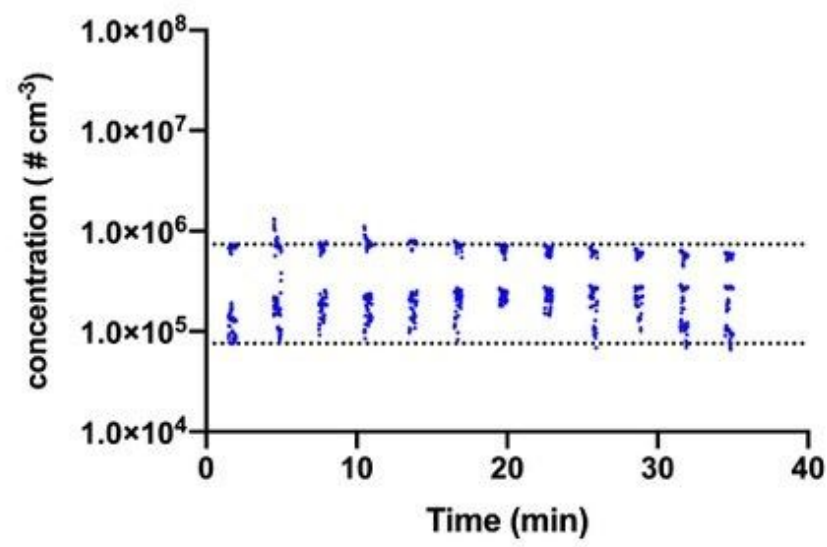

6

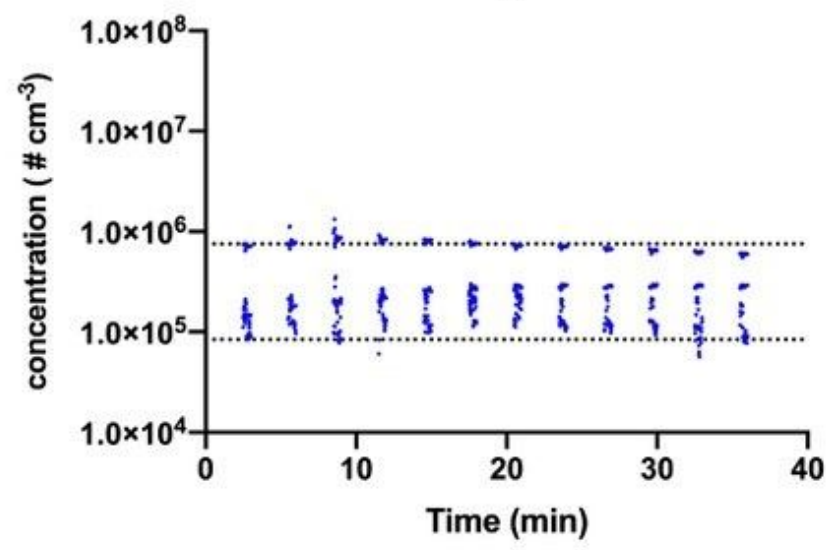

Figure 5

Total particle concentration generated during AGPs in the presence of HVS(IO) (group B; Table 2) at each air sampling location ( $1-6$; Table 1$)$. Acquisition of air samples were performed during the baseline period $(0-3 \mathrm{~min})$, during the six procedures $(3-18 \mathrm{~min})$ and following cessation of procedures $(18-36$ 
$\mathrm{min})$. Dotted lines indicate the upper and lower boundaries of the baseline data. Each data point represents the sum of particles measured by HR-ELPI over 1 second during each replicate $(n=3)$.

1

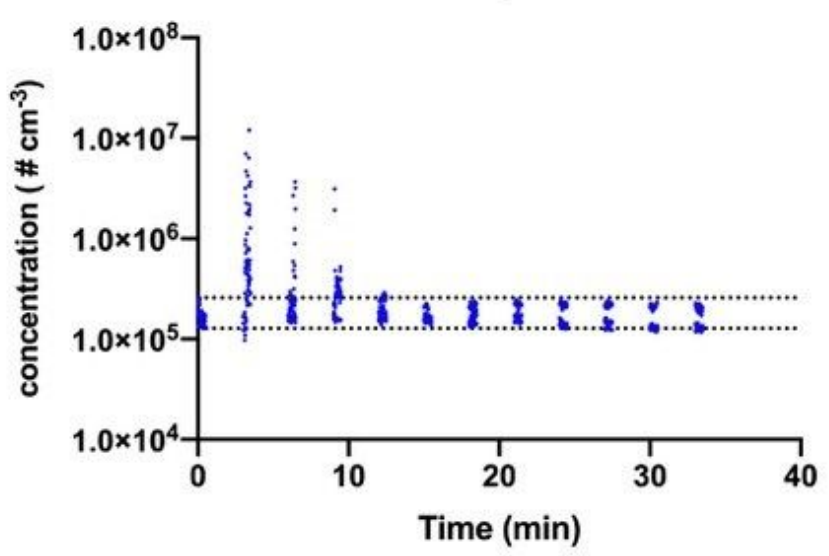

3

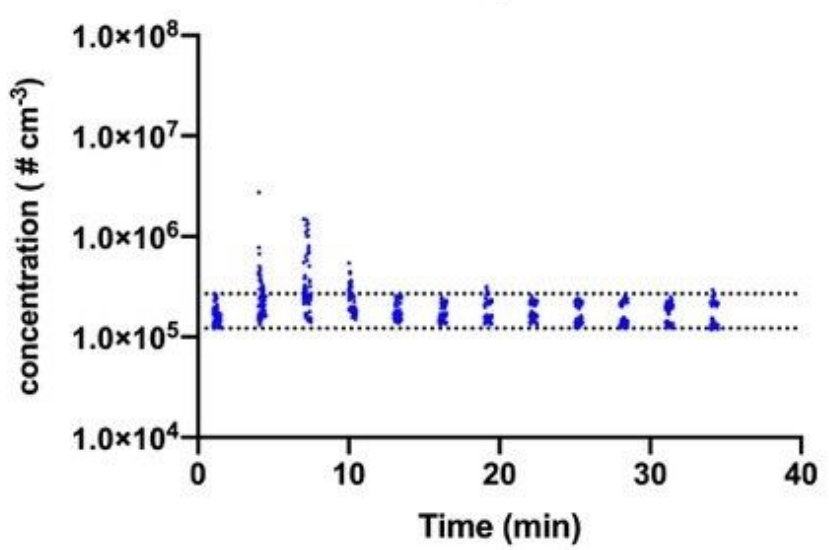

5

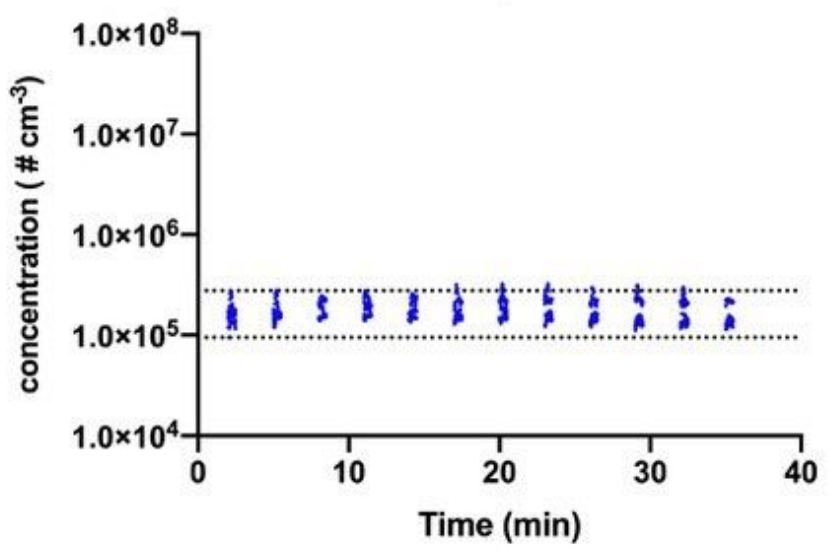

2

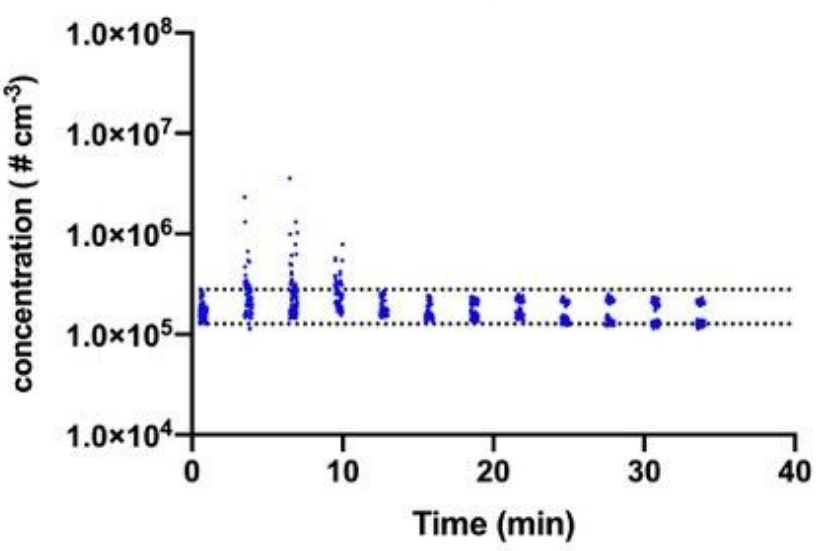

4

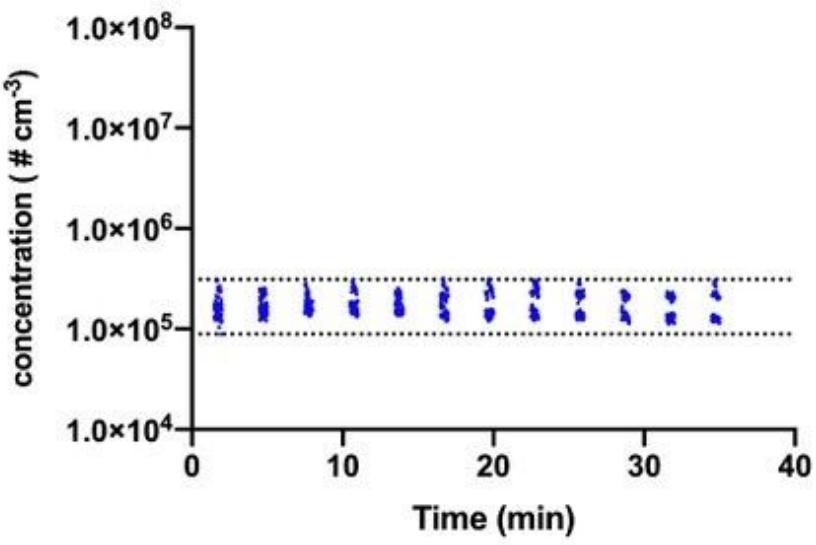

6

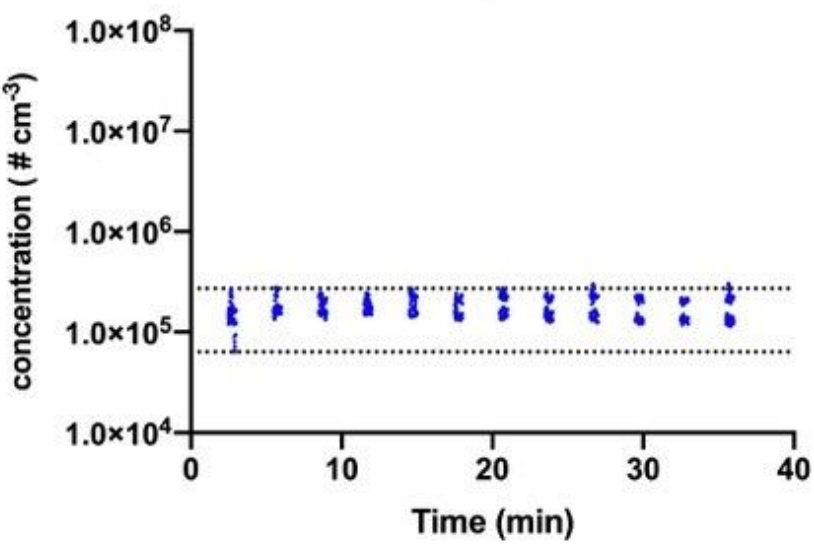

Figure 6

Total particle concentration generated during AGPs in the presence of HVS(IO) and ACS (group C; Table 2 ) at each air sampling location (1 - 6; Table 1). Acquisition of air samples were performed during the baseline period $(0-3 \mathrm{~min})$, during the six procedures $(3-18 \mathrm{~min})$ and following cessation of procedures 
(18 - $36 \mathrm{~min}$ ). Dotted lines indicate the upper and lower boundaries of the baseline data. Each data point represents the sum of particles measured by HR-ELPI over 1 second during each replicate $(n=3)$.

1

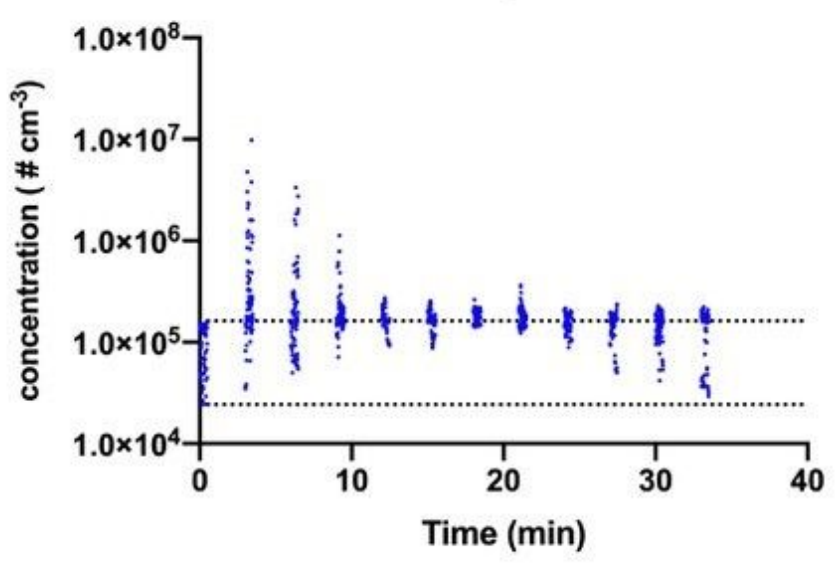

3

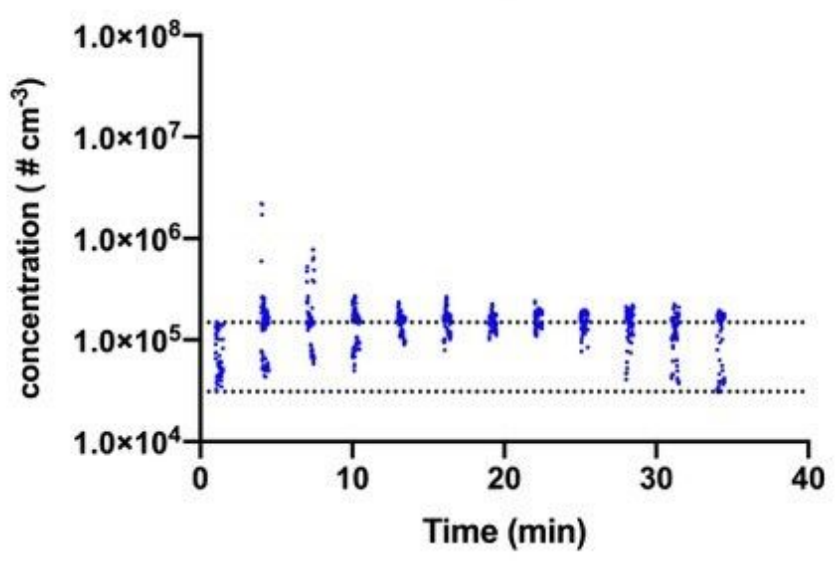

5

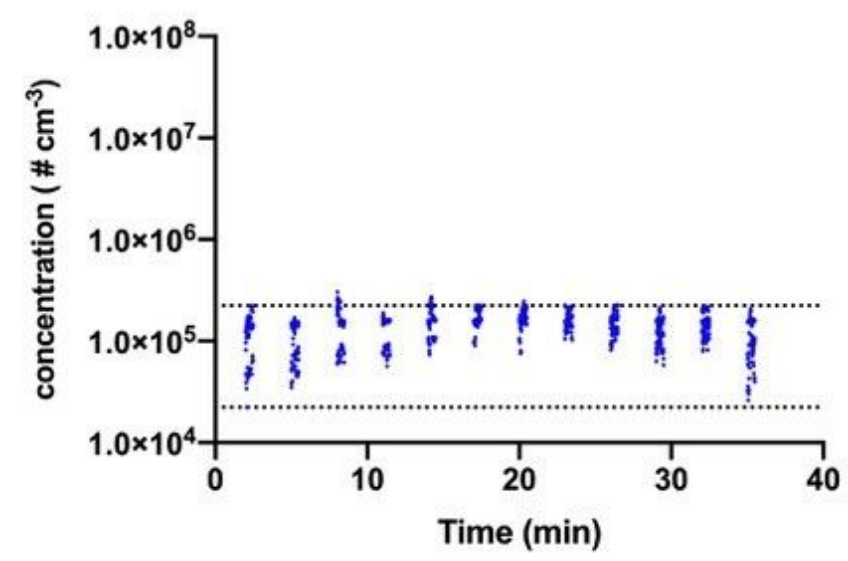

2

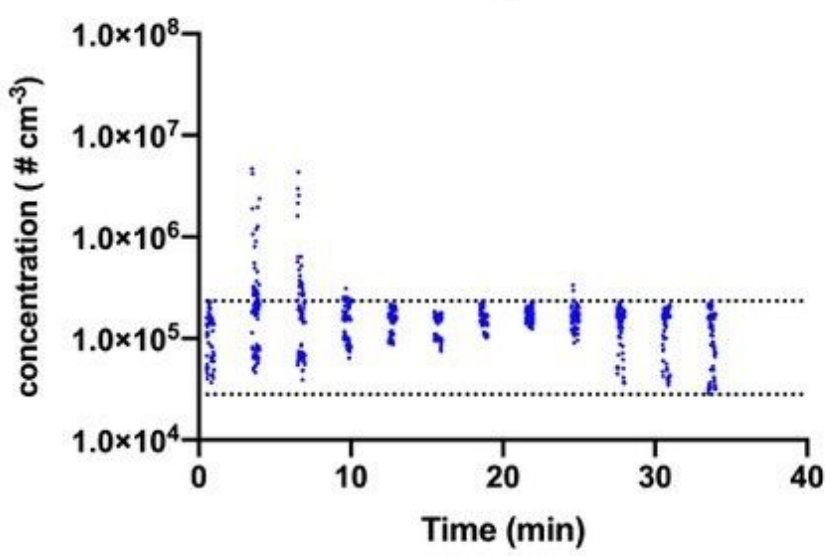

4

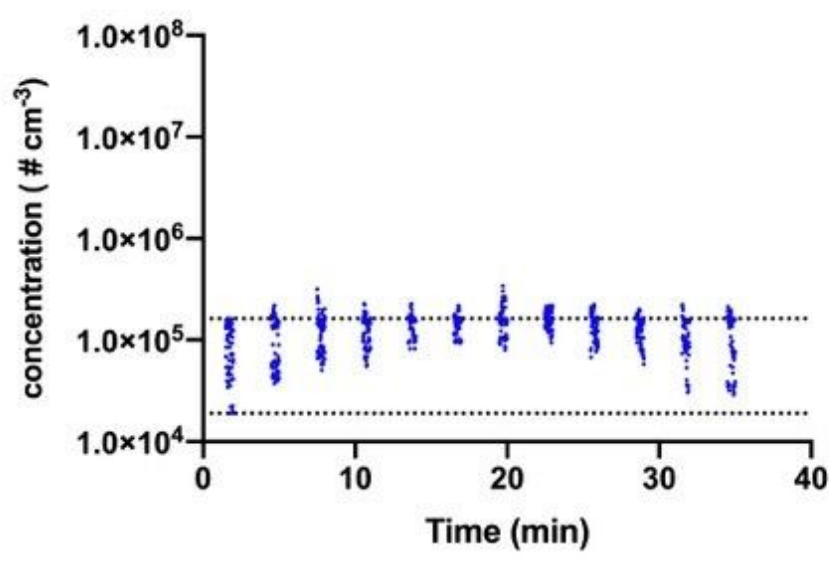

6

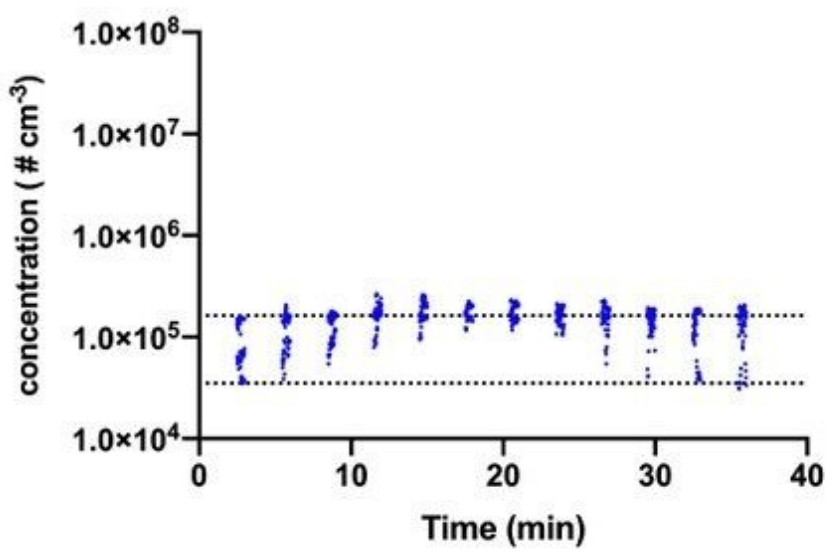

Figure 7

Total particle concentration generated during AGPs in the presence of HVS(IO) and HVS(EO) (group D; Table 2$)$ at each air sampling location (1 - 6; Table 1). Acquisition of air samples were performed during the baseline period $(0-3 \mathrm{~min})$, during the six procedures ( $3-18 \mathrm{~min})$ and following cessation of 
procedures (18 - $36 \mathrm{~min})$. Dotted lines indicate the upper and lower boundaries of the baseline data. Each data point represents the sum of particles measured by HR-ELPI over 1 second during each replicate $(n=3)$.

1

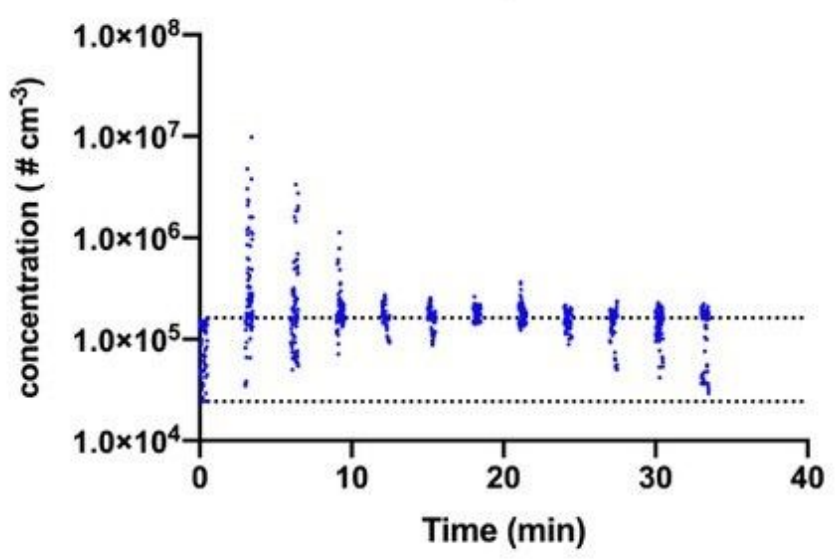

3

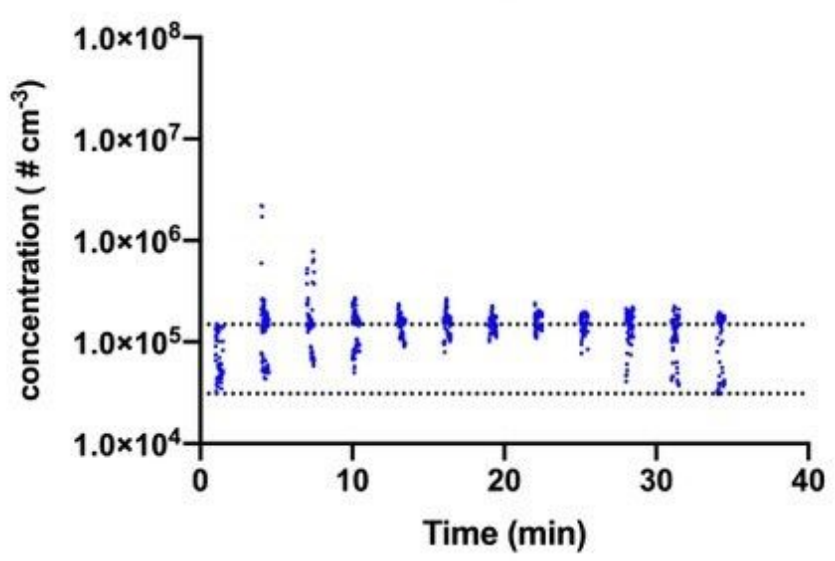

5

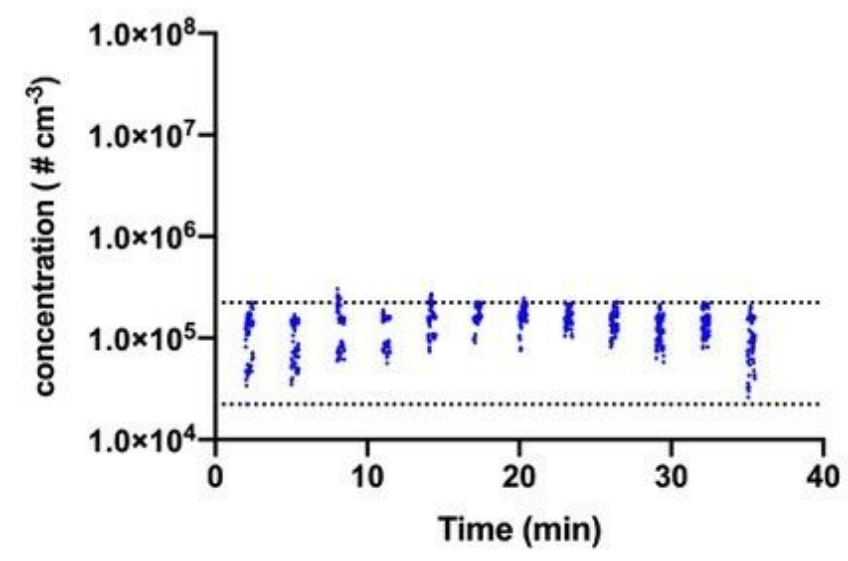

2

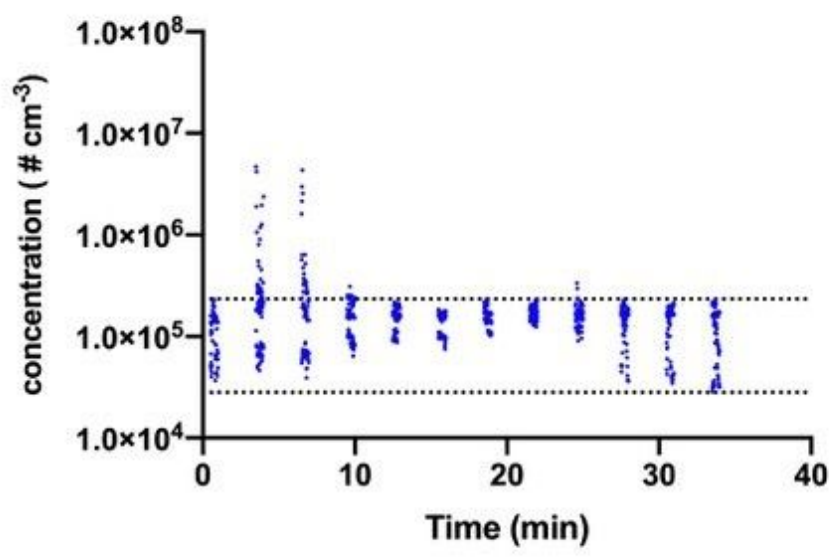

4

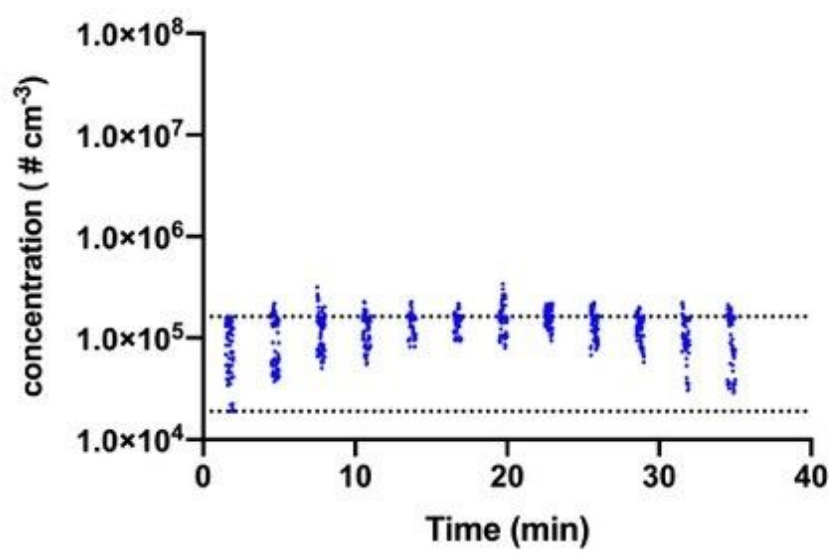

6

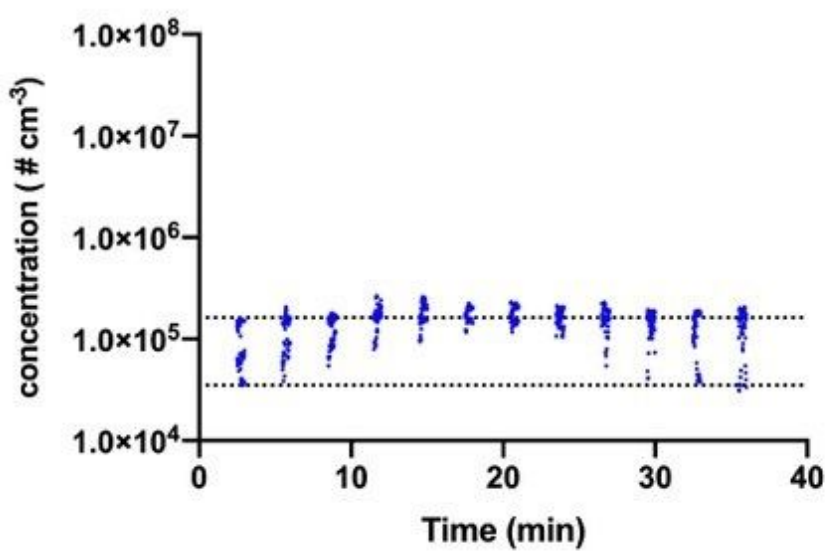

Figure 8

Total particle concentration generated during AGPs in the presence of HVS(IO), HVS(EO) and ACS (group $\mathrm{E}$; Table 2) at each air sampling location (1 - 6; Table 1). Acquisition of air samples were performed 
during the baseline period $(0-3 \mathrm{~min})$, during the six procedures $(3-18 \mathrm{~min})$ and following cessation of procedures (18 - $36 \mathrm{~min})$. Dotted lines indicate the upper and lower boundaries of the baseline data.

Each data point represents the sum of particles measured by HR-ELPI over 1 second during each replicate $(n=3)$.

1

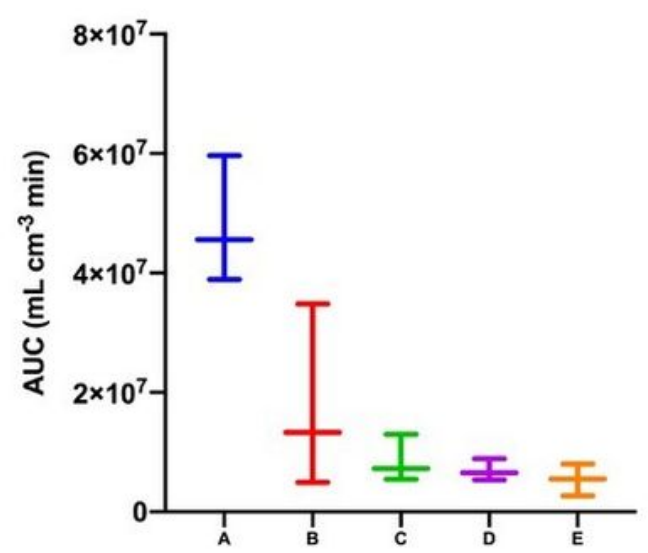

3

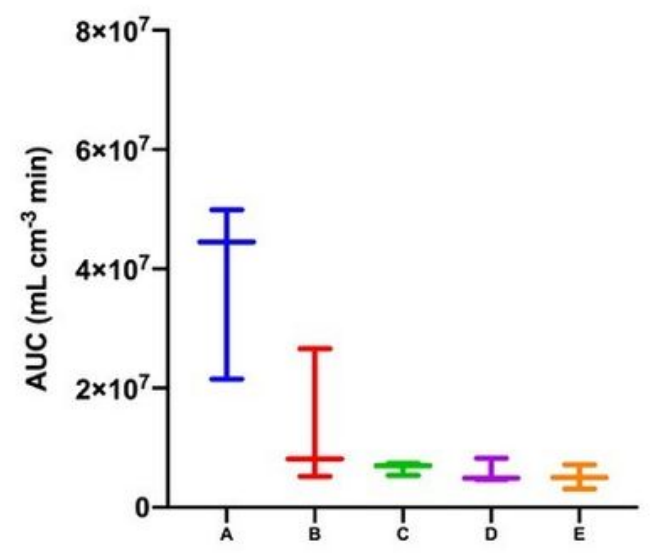

5

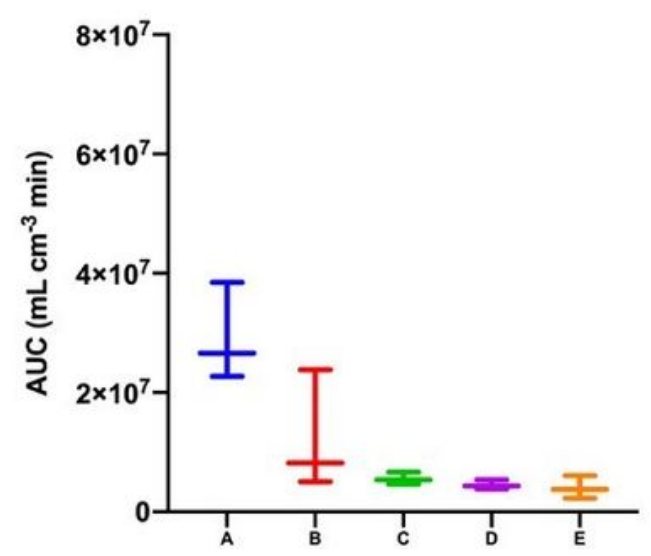

2

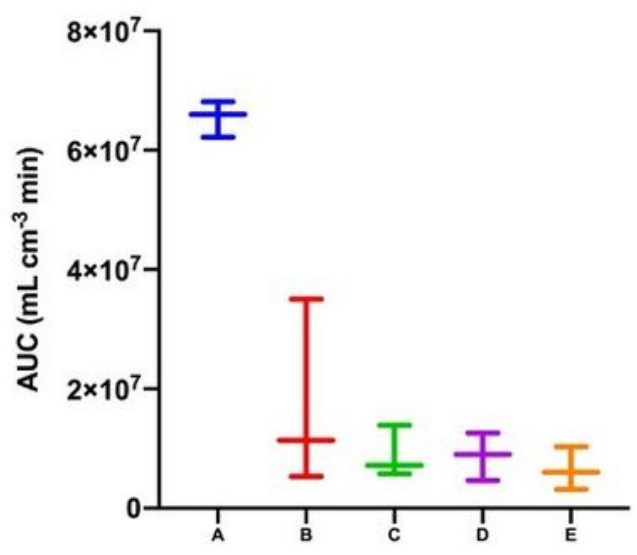

4

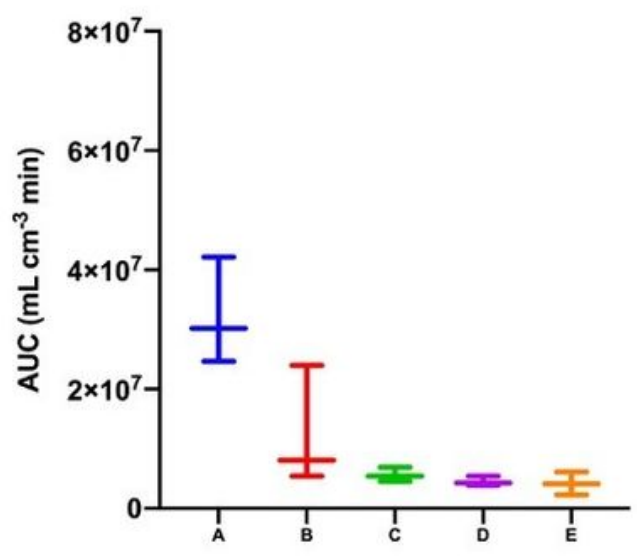

6

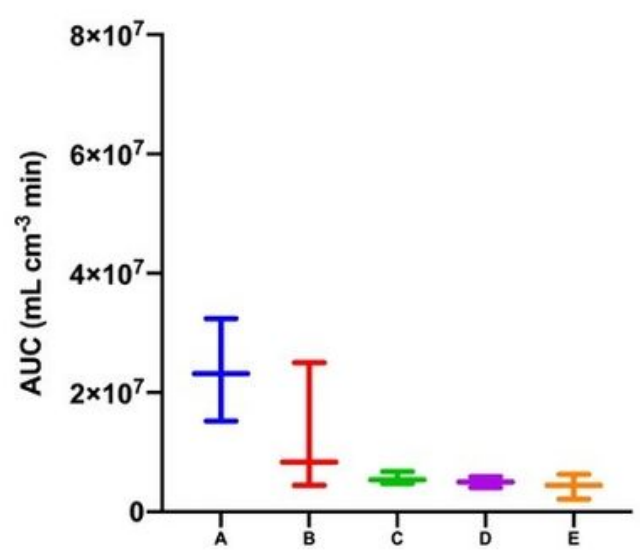

Figure 9 
Total dose of particles measured over the 36-minute experimental period (expressed as area under curve) for each location ( $1-6$; Table 1$)$ and treatment group (A - E; Table 2). Each data point represents the median \pm minimum/maximum of $\mathrm{n}=3$ replicates.

1

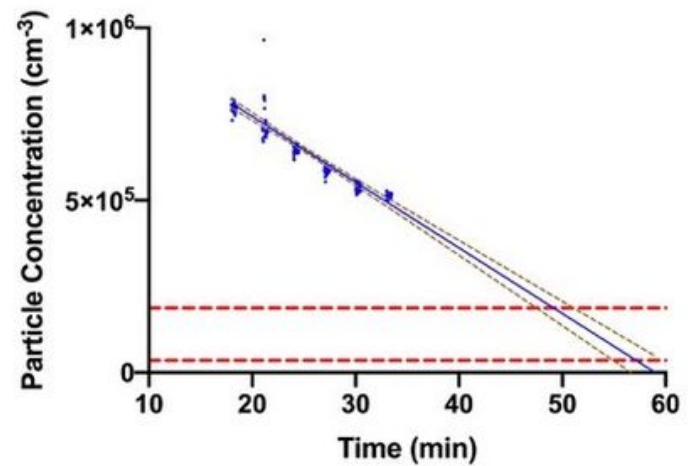

3

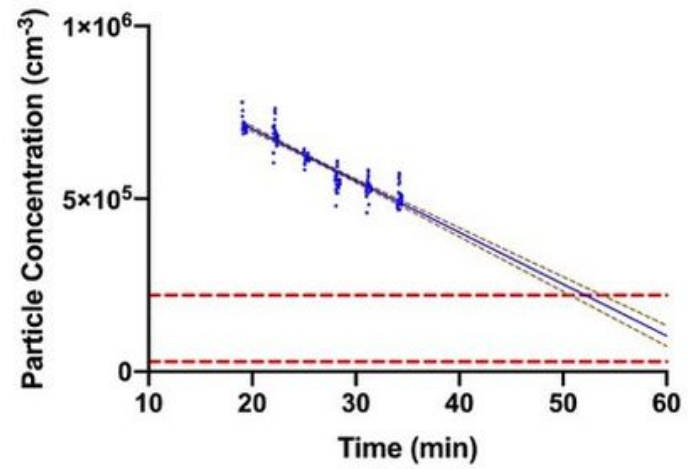

5

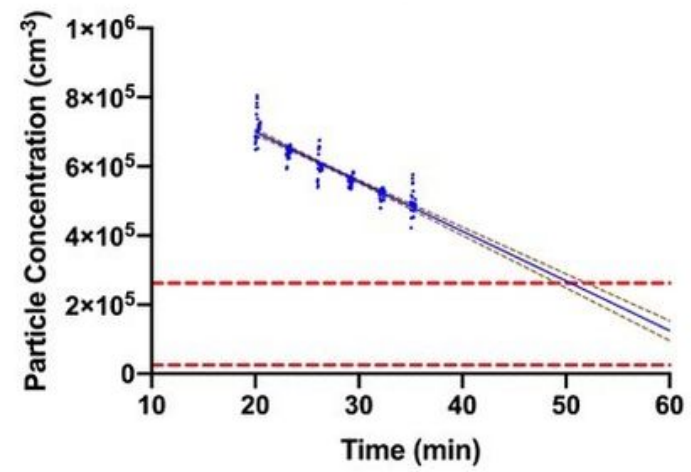

2

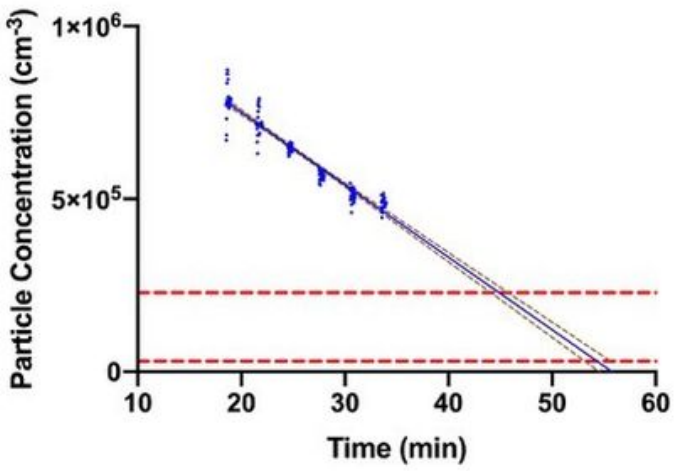

4

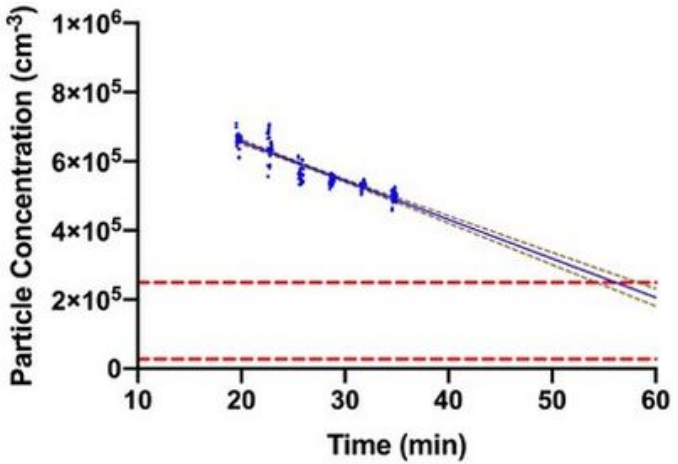

6

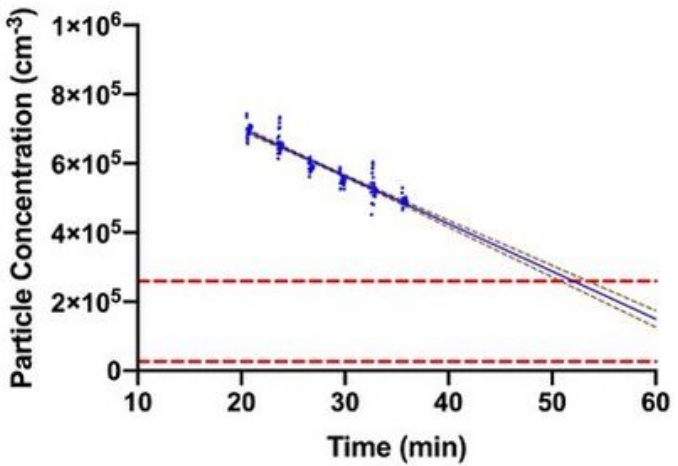

\begin{tabular}{|c|c|c|c|c|c|c|}
\hline Regression & \multicolumn{7}{|c|}{ Location } \\
\cline { 2 - 7 } parameter & 1 & 2 & 3 & 4 & 5 & 6 \\
\hline Y-Intercept & $1.1 \mathrm{E}+06$ & $1.2 \mathrm{E}+06$ & $1.0 \mathrm{E}+06$ & $8.8 \mathrm{E}+05$ & $9.9 \mathrm{E}+05$ & $9.8 \mathrm{E}+05$ \\
\hline Slope & $-1.9 \mathrm{E}+04$ & $-2.1 \mathrm{E}+04$ & $-1.5 \mathrm{E}+04$ & $-1.1 \mathrm{E}+04$ & $-1.4 \mathrm{E}+04$ & $-1.4 \mathrm{E}+04$ \\
\hline $\mathrm{r}^{2}$ & 0.7967 & 0.9218 & 0.8609 & 0.8273 & 0.8533 & 0.8827 \\
\hline
\end{tabular}

Figure 10

Linear regression (with 95\% confidence intervals) of decay-phase particle concentration data. Each data point represents the median sum particle concentration measured by HR-ELPI per second during each 
replicate $(n=3)$. Horizontal dotted red lines indicate baseline particle range.

\section{Supplementary Files}

This is a list of supplementary files associated with this preprint. Click to download.

- SupplementarydataAnnexAFinalEdit2.pdf 